\title{
Habits in healthy nutrition, obesity, alcohol, smoking, among students of the faculty of physical activity and recreation
}

\author{
ROBERT ÇITOZI ${ }^{1}$, DHURATA BOZO ${ }^{2}$ \\ ${ }^{1}$ Faculty of Physical Activity and Recreation, Department of Physical Activity Recreation and Tourism \\ 2 Sport Sciences Research Institute, University of Sport of Tirana, Albania
}

\begin{abstract}
Çitozi, R. \& Bozo, Dh. (2014). Habits in healthy nutrition, obesity, alcohol, smoking, among students of the faculty of physical activity and recreation. J. Hum. Sport Exerc., 9(Proc1), pp.S291-S299. The deep economic and social transformation that began in Albania in the early 1990s has brought about remarkable changes to the structure of its economy and the living standards of its people. As a consequence, the dietary habits of young adults have been affected; thus, overweight and obesity are increasingly being observed among the young. The purpose of this study is to assess the prevalence of overweight and obesity on a sample of students from the Sports University of Tirana and to examine their eating habits. A cross-sectional survey of 80 students ( $57.5 \%$ male and $42.5 \%$ female), aged 18.46 years, were chosen randomly from the Sports University of Tirana (SUT) during October 2013. Students were asked to fill out a self-reported questionnaire that included questions on their eating, drinking and smoking habits. Also, their weight, height, and body mass index were measured. Body mass index (BMI) was used to assess students' weight status. This study showed that the majority of the students $(78.88 \%)$ were of normal weight $(73.7 \%$ male students compared to $82.6 \%$ female students). The prevalence of overweight and obesity was not common among male students compared to females $(23.6 \%$ and $10.3 \%$ vs. $2.2 \%$ and $1.2 \%$, respectively). In contrast, $5.9 \%$ female students were underweight as compared to $0.5 \%$ males. Eating habits of the students showed that the majority $(70 \%)$ reported taking meals regularly. Healthier eating habits of female compared to male students in terms of daily breakfast intake are the same. $38.23 \%$ of female students reported eating breakfast daily compared to $45.65 \%$ of male students. Intake of colored vegetables and fruits was common among students. A total of $32.5 \%$ reported daily intake of colored vegetables with a small gender differences ( $32.35 \%$ females vs. $32.6 \%$ males). Alcohol intake to male students in terms of 2 or 3 times per week was $2.17 \%$ and rarely $56.52 \%$, while to females students was $2.94 \%$ and rarely $35.29 \%$. Males at least 1 packet is $23.91 \%$ and rarely $15.21 \%$, females at least 1 packet is $11.76 \%$ and rarely $5.88 \% .70 \%$ of our students are never smoker. In spite of the overall low prevalence of overweight and obesity in the studied sample, results indicate that university of sport students would possibly benefit from a nutrition and health promotion program to reduce the tendency of overweight and obesity, especially among male students, and to improve students' eating habits. Key words: HEALTHY FOOD, BMI, EATING HABITS, GENDER DIFFERENCES.
\end{abstract}

Corresponding author. Faculty of Physical Activity and Recreation, Department of Physical Activity Recreation and Tourism E-mail: rcitozi@yahoo.com

8th INSHS International Christmas Sport Scientific Conference, 5-7 December 2013. International Network of Sport and Health Science. Szombathely, Hungary.

JOURNAL OF HUMAN SPORT \& EXERCISE ISSN 1988-5202

(c) Faculty of Education. University of Alicante

doi:10.14198/jhse.2014.9.Proc1.12 


\section{INTRODUCTION}

After the liberalization of the economy in the early 1990s, the daily supply of many food groups (fruit and vegetables, meat and offal, milk and eggs) increased. The supply is still characterized by the high share of cereals. However, their supply is reduced, giving way to an increase of other food groups, particularly dairy products, fruit and vegetables and meat. The daily supply of starchy roots, fruit and vegetables, milk, eggs and meat are more than doubled compared with the 1986/88 period. The increase suggests that diversity of the diet is improving for a major part of the population. On the contrary, cereal consumption was reduced about by one-third during the same period. This was caused by trade liberalization, shifting of the food supply from the traditional domestic production to imported products, together with life style changes (Food safety As in Mediterranean countries).

Dietary habits of young adults are affected by the fast-food market. As a consequence, overweight and obesity are increasingly observed among the young. Obesity in combination with unhealthy life style, such as smoking, alcohol and physical inactivity, may increase the risk of chronic diseases. In this regard, nutritional knowledge may act as a deterrent against fast-food trend. Thus, sport universities may contribute significantly in reducing the prevalence of obesity among the young population through the promotion of healthy eating habits. The purpose of this study was to assess the prevalence of overweight and obesity in a sample of students from the Sports University of Tirana and examine their eating habits. Assessing students' weight status and eating habits will help health educators to develop proper nutrition-related education programs that promote healthy food choices and good eating habits.

\section{METHODS}

\section{Design and sample}

The study design was a cross-sectional survey conducted at the Sports University of Tirana (SUT) during October 2013. A sample of 80 students ( $57.5 \%$ male and $42.5 \%$ female), aged 18.46 years participated in this study. Students were recruited randomly by a trained student accompanied by an (SUT) professor. The response rate among students was high. Students who agreed to participate in this study were asked to sign a consent form according to Helsinki declaration, (Ethical Principles for Medical Research Involving Human Subjects).

\section{Data Collection}

Data collection took place in two steps. The first step was to fill out the questionnaire and the second step was to perform the anthropometric measurements. Recruited students were asked to fill out a questionnaire related to their eating, drinking and smoking habits. The questionnaire was adopted from a previously published study where authors have standardized its use among university students (Sakamaky et al., 2005). Prior to questionnaire administration, students were informed by an (SUT) professor about the study. They were given instructions on how to fill out the questionnaire completely and truthfully. After filling out the questionnaire, anthropometric measurements, such as weight and height, and body mass index, were done. As fluctuations in body hydration status may affect body composition results, measurements were taken in the morning (at least three hours after waking up) when students were on an empty bladder, not having exercise, food or drink for at least three hours before having the measurements. Height measurements were taken with a secured metal ruler. Students were asked to take off their shoes for height measurements. Body mass index (BMI) was used to assess students' weight status. According to guidelines stated by the National Institutes of Health, weight status was classified into four categories: 
1- $\quad$ Underweight $(\mathrm{BMI} \leq 18.5)$

2- $\quad$ Normal weight (BMl between $18.5-24.9$ )

3- $\quad$ Overweight (BMl between 25-29.9)

4- $\quad$ Obese $(\mathrm{BMI} \geq 30)$ (BMl for adults)

\section{RESULTS}

Characteristics of the students' sample and BMI values

Characteristics of the participated students are presented in Table 1. A total of 80 students (46 males and 34 females), with a mean age of 18.46 years, participated in this study. The average weight and height of the participated students were $62.6 \mathrm{~kg}$ and $1.71 \mathrm{~cm}$, respectively. Mean BMI was 21.17 .

Table 1. Characteristics of the participants

\begin{tabular}{lccc} 
Variable & Total & Males & Females \\
\hline Number of Students & $\mathrm{N}=80$ & $\mathrm{~N}=46$ & $\mathrm{~N}=34$ \\
Age (years) & 18.46 & 18.92 & 18.00 \\
Weight (kg) & 62.6 & 70.76 & 54.45 \\
Height (cm) & 1.71 & 1.77 & 165 \\
BMII & 21.17 & 22.33 & 20.01 \\
\hline
\end{tabular}

Students' weight status based on BMI categories

The majority of the students $(78.88 \%)$ were of normal weight $(73.7 \%$ male students compared to $82.6 \%$ female students). The prevalence of overweight and obesity was not common among male students compared to females $(23.6 \%$ and $10.3 \%$ vs. $2.2 \%$ and $1.2 \%$, respectively). In contrast, $5.9 \%$ female students were underweight as compared to $0.5 \%$ males.

Table 2. Prevalence of obesity among students based on BMI by gender

\begin{tabular}{|c|c|c|c|c|c|c|}
\hline \multirow[b]{2}{*}{ Weight Status } & \multicolumn{2}{|c|}{ Males } & \multicolumn{2}{|c|}{ Females } & \multicolumn{2}{|c|}{ Total } \\
\hline & $N=$ & Percentage & $N=$ & Percentage & $N=$ & Percentage \\
\hline Underweight* & 1 & 0.5 & 2 & 5.9 & 3 & 3.2 \\
\hline Normal ${ }^{* *}$ & 33 & 73.7 & 28 & 82.6 & 61 & 78.88 \\
\hline Overweight $t^{* * *}$ & 10 & 23.6 & 3 & 10.3 & 13.5 & 16.25 \\
\hline Obese $e^{* * * *}$ & 2 & 2.2 & 1 & 1.2 & 2.5 & 1.67 \\
\hline
\end{tabular}

Underweight (BMI $\leq 18.5)$, ** Normal (BMI between $18.5-24.9)$, *** Overweight (BMI between $25-29.9$ ), $\approx * \div \div$ Obese $(\mathrm{BMII} \geq 30$ ). 


\section{Students' eating habits}

Eating habits of the students showed that the majority $(70 \%)$ reported taking meals regularly. Healthier eating habits of female compared to male students in terms of daily breakfast intake are not the same. $38.23 \%$ of female students reported eating breakfast daily compared to $45.65 \%$ of male students. Intake of colored vegetables and fruits was common among students. A total of $32.5 \%$ reported daily intake of colored vegetables with a small gender differences ( $32.35 \%$ females vs. $32.6 \%$ males). Alcohol intake to male students in terms of 2 or 3 times per week was $2.17 \%$ and rarely $56.52 \%$, while to female's students was $2.94 \%$ and rarely $35.29 \%$. Males at least 1 packet daily smoking is $23.91 \%$ and rarely $15.21 \%$, females at least 1 packet is $11.76 \%$ and rarely $5.88 \% .70 \%$ of our students are never smoker.

Table 3. Question 1. Do you take your meals regularly?

\begin{tabular}{lccccccc}
\hline \multirow{1}{*}{ Question } & Levels & Total & MALES & MALES & FEMALES & FEMALES & TOTAL \\
& & & $\mathbf{N}=\mathbf{4 6}$ & $\%$ & $\mathbf{N}=\mathbf{3 4}$ & $\%$ & $\%$ \\
\hline $\begin{array}{l}\text { 1-Do you take your } \\
\text { meals regularly? }\end{array}$ & Always & 7 & $\mathbf{6}$ & $\mathbf{1 3 . 0 5}$ & $\mathbf{1}$ & $\mathbf{2 . 9 4}$ & $\mathbf{3 . 7 5}$ \\
& Regular & 56 & 34 & 73.9 & 22 & 64.7 & 70 \\
& Irregular & $\mathbf{1 7}$ & $\mathbf{6}$ & $\mathbf{1 3 . 0 5}$ & $\mathbf{1 1}$ & $\mathbf{3 2 . 3 5}$ & $\mathbf{2 1 . 2 5}$ \\
\hline
\end{tabular}

Table 4. Question 2. Do you take breakfast?

\begin{tabular}{|c|c|c|c|c|c|c|c|}
\hline \multirow{3}{*}{ Question } & \multirow{3}{*}{ Levels } & Total & MALES & MALES & FEMALES & FEMALES & TOTAL \\
\hline & & \multirow{2}{*}{\multicolumn{6}{|c|}{$\mathrm{N}=\mathbf{3 4}$}} \\
\hline & & & & & & & \\
\hline \multirow{5}{*}{$\begin{array}{l}\text { 2-Do you take } \\
\text { breakfast? }\end{array}$} & Daily & 34 & 21 & 45.65 & 13 & 38.23 & 42.5 \\
\hline & $\begin{array}{l}\text { Three or four } \\
\text { times per } \\
\text { week }\end{array}$ & 12 & 10 & 21.73 & 2 & 5.88 & 15 \\
\hline & Once or twice & 10 & 6 & 13.04 & 4 & 11.76 & 12.5 \\
\hline & perweek & 24 & 9 & 19.56 & 15 & 44.11 & 30 \\
\hline & Rarely & & & & & & \\
\hline
\end{tabular}

Table 5. Question 3. How many times do you eat meals except snacks? 


\begin{tabular}{|c|c|c|c|c|c|c|c|}
\hline Question & Levels & Total & $\begin{array}{l}\text { MALES } \\
\mathrm{N}=46\end{array}$ & $\begin{array}{l}\text { MALES } \\
\%\end{array}$ & $\begin{array}{c}\text { FEMALES } \\
\qquad \begin{array}{c}\mathrm{N}=\mathbf{3 4}\end{array}\end{array}$ & $\begin{array}{c}\text { FEMLAES } \\
\%\end{array}$ & $\begin{array}{c}\text { TOTAL } \\
\%\end{array}$ \\
\hline & & $\mathrm{N}=\mathbf{8 0}$ & & & & & \\
\hline \multirow{4}{*}{$\begin{array}{l}\text { 3-How many times } \\
\text { do you eat meals } \\
\text { except snacks? }\end{array}$} & One time & 4 & 1 & 2.17 & 3 & 8.82 & 5 \\
\hline & Two times & 23 & 7 & 15.21 & 16 & 47.05 & 28.75 \\
\hline & Three times & 48 & 35 & $76.0 \mathrm{~s}$ & 13 & 38.23 & 60 \\
\hline & Four times & 5 & 3 & 6.52 & 2 & 5.88 & 6.25 \\
\hline
\end{tabular}

Table 6. Question 4. How often do you take snacks apart from regular meals?

\begin{tabular}{|c|c|c|c|c|c|c|c|}
\hline \multirow{3}{*}{ Question } & \multirow{3}{*}{ Levels } & Total & MALES & MALES & FEMALES & FEMALES & TOTAL \\
\hline & & \multirow{2}{*}{\multicolumn{6}{|c|}{$\mathrm{N}=\mathbf{S 0}$}} \\
\hline & & & & & & & \\
\hline \multirow{5}{*}{$\begin{array}{l}\text { 4-How of ten do you } \\
\text { take snacks apart } \\
\text { from regular meals? }\end{array}$} & Daily & 20 & 13 & 28.26 & 7 & 20.58 & 25 \\
\hline & & 24 & 20 & 4347 & 4 & 11.76 & 30 \\
\hline & times per week & & & & & & \\
\hline & $\begin{array}{l}\text { Once or twice } \\
\text { per week }\end{array}$ & 26 & 10 & 21.73 & 16 & 47.05 & 32.5 \\
\hline & Rarely & 10 & 3 & 6.52 & 7 & 20.58 & 12.5 \\
\hline
\end{tabular}

Table 7. Question 5. How often do you eat vegetables?

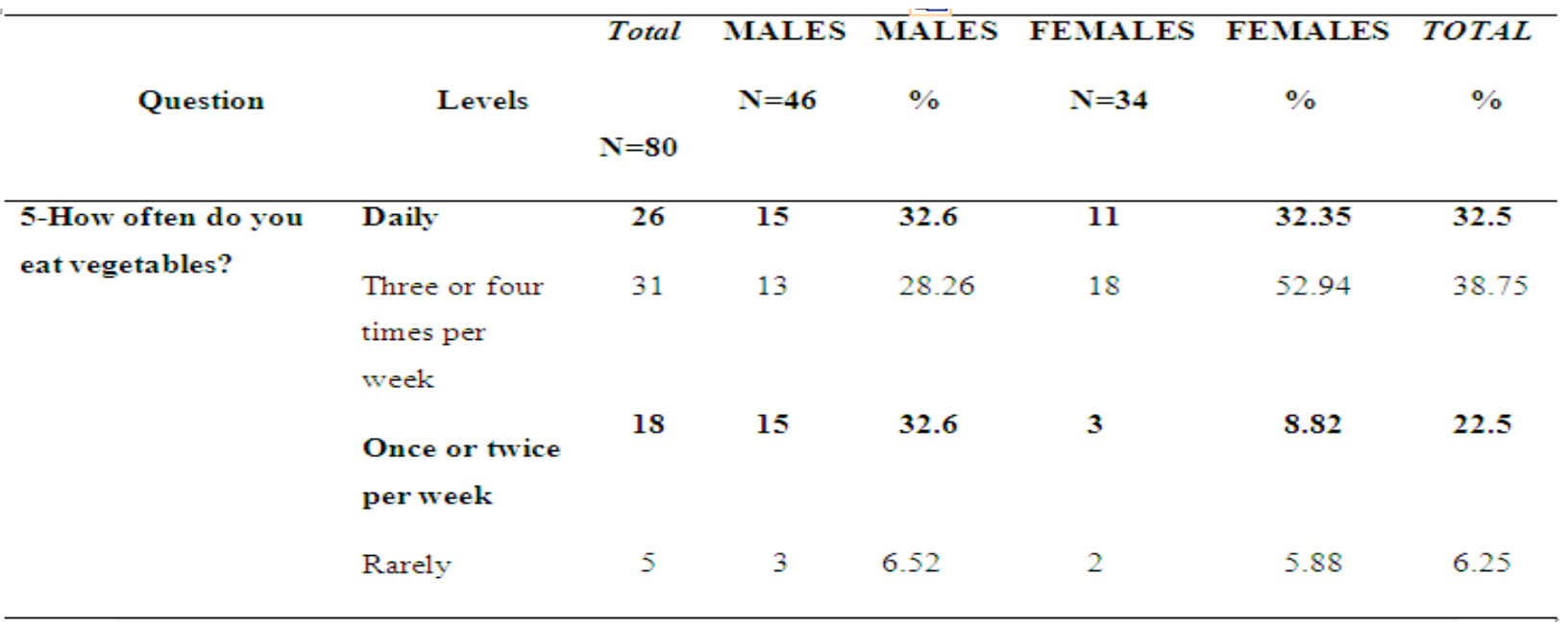

Table 8. Question 6. How often do you eat fruits? 


\begin{tabular}{|c|c|c|c|c|c|c|c|}
\hline \multirow[t]{2}{*}{ Question } & \multirow[t]{2}{*}{ Levels } & Total & $\begin{array}{l}\text { MALES } \\
\mathrm{N}=46\end{array}$ & $\begin{array}{c}\text { MALES } \\
\%\end{array}$ & $\begin{array}{c}\text { FEMALES } \\
\mathbf{N}=\mathbf{3 4}\end{array}$ & $\begin{array}{c}\text { FEMALES } \\
\%\end{array}$ & $\begin{array}{c}\text { TOTAL } \\
\%\end{array}$ \\
\hline & & \multicolumn{6}{|l|}{$\mathrm{N}=\mathbf{8 0}$} \\
\hline \multirow{5}{*}{$\begin{array}{l}\text { 6-How of ten do you } \\
\text { eat fruits? }\end{array}$} & Daily & 42 & 20 & 43.47 & 22 & 64.7 & 52.5 \\
\hline & Three or four & 25 & 18 & 39.13 & 7 & 20.58 & \multirow{3}{*}{31.25} \\
\hline & times per week & & & & & & \\
\hline & $\begin{array}{l}\text { Once or twice } \\
\text { per week }\end{array}$ & 10 & 6 & 13.04 & 4 & 11.76 & \\
\hline & Rarely & 3 & 2 & 4.35 & 1 & 2.94 & 3.75 \\
\hline
\end{tabular}

Table 9. Question 7. How often do you eat fried food?

\begin{tabular}{|c|c|c|c|c|c|c|c|}
\hline \multirow[t]{2}{*}{ Question } & Levels & Total & $\begin{array}{l}\text { MALES } \\
\mathrm{N}=46\end{array}$ & $\begin{array}{c}\text { MALES } \\
\%\end{array}$ & $\begin{array}{c}\text { FEMALES } \\
\mathrm{N}=\mathbf{3 4}\end{array}$ & $\begin{array}{c}\text { FEMALES } \\
\%\end{array}$ & $\begin{array}{c}\text { TOTAL } \\
\%\end{array}$ \\
\hline & & \multicolumn{6}{|l|}{$\mathrm{N}=\mathbf{8 0}$} \\
\hline \multirow{5}{*}{$\begin{array}{l}\text { 7-How often do you } \\
\text { eat fried food? }\end{array}$} & Daily & 28 & 18 & 39.13 & 10 & 29.41 & 35 \\
\hline & Three or four & & & & & & \\
\hline & times per week & 38 & 22 & 47.82 & 16 & 47.05 & 47.5 \\
\hline & $\begin{array}{l}\text { Once or twice } \\
\text { perweek }\end{array}$ & s & 4 & 8.69 & 4 & 11.76 & 10 \\
\hline & Rarely & 6 & 2 & 4.35 & 4 & 11.76 & 7.5 \\
\hline
\end{tabular}

Table 10. Question 8. How often do you eat with friends and family?

\begin{tabular}{|c|c|c|c|c|c|c|c|}
\hline Question & Levels & Total & $\begin{array}{l}\text { MALES } \\
\mathrm{N}=46\end{array}$ & $\begin{array}{l}\text { MALES } \\
\%\end{array}$ & $\begin{array}{c}\text { FEMALES } \\
\qquad \begin{array}{c}\mathrm{N}=\mathbf{3 4}\end{array}\end{array}$ & $\begin{array}{c}\text { FEMALES } \\
\%\end{array}$ & $\begin{array}{c}T O T A L \\
\%\end{array}$ \\
\hline & & $\mathbf{N}=\mathbf{8 0}$ & & & & & \\
\hline \multirow{5}{*}{$\begin{array}{l}\text { S-How of ten do you } \\
\text { eat with friends and } \\
\text { family? }\end{array}$} & Daily & 27 & 10 & 21.73 & 17 & 50 & 33.75 \\
\hline & Three or four & & & & & & \\
\hline & times per week & 8 & 3 & 6.52 & 5 & 14.7 & 10 \\
\hline & $\begin{array}{l}\text { Once or twice } \\
\text { per week }\end{array}$ & 10 & 7 & 15.21 & 3 & 8.82 & 12.5 \\
\hline & Rarely & 35 & 26 & 56.52 & 9 & 26.47 & 43.75 \\
\hline
\end{tabular}

Table 11. Question 9. What type of food do you think you should eat to have a balanced nutrition? 


\begin{tabular}{|c|c|c|c|c|c|c|c|}
\hline Question & Levels & Total & $\begin{array}{l}\text { MALES } \\
\mathrm{N}=46\end{array}$ & $\begin{array}{c}\text { MALES } \\
\%\end{array}$ & $\begin{array}{c}\text { FEMALES } \\
\qquad \begin{array}{c}\mathrm{N}=\mathbf{3 4}\end{array}\end{array}$ & $\begin{array}{c}\text { FEMALES } \\
\%\end{array}$ & $\begin{array}{c}\text { TOTAL } \\
\%\end{array}$ \\
\hline & & $\mathrm{N}=\mathbf{S 0}$ & & & & & \\
\hline \multirow{5}{*}{$\begin{array}{l}\text { 9-What type of food } \\
\text { do you think you } \\
\text { should eat to have a } \\
\text { balanced nutrition? }\end{array}$} & Mainly meat & 12 & 9 & 19.56 & 3 & $\mathbf{8 . 8 2}$ & 15 \\
\hline & $\begin{array}{l}\text { Mainly } \\
\text { vegetables }\end{array}$ & 16 & 7 & 15.21 & 9 & 26.47 & 20 \\
\hline & $\begin{array}{l}\text { Meat, } \\
\text { vegetables and }\end{array}$ & 38 & 20 & 43.47 & 18 & 52.94 & 47.5 \\
\hline & $\begin{array}{l}\text { other variety } \\
\text { of foods }\end{array}$ & 14 & 10 & 21.73 & 4 & 11.76 & 17.5 \\
\hline & Fast-Food & & & & & & \\
\hline
\end{tabular}

Table 12. Question 10. How often do you drink alcohol?

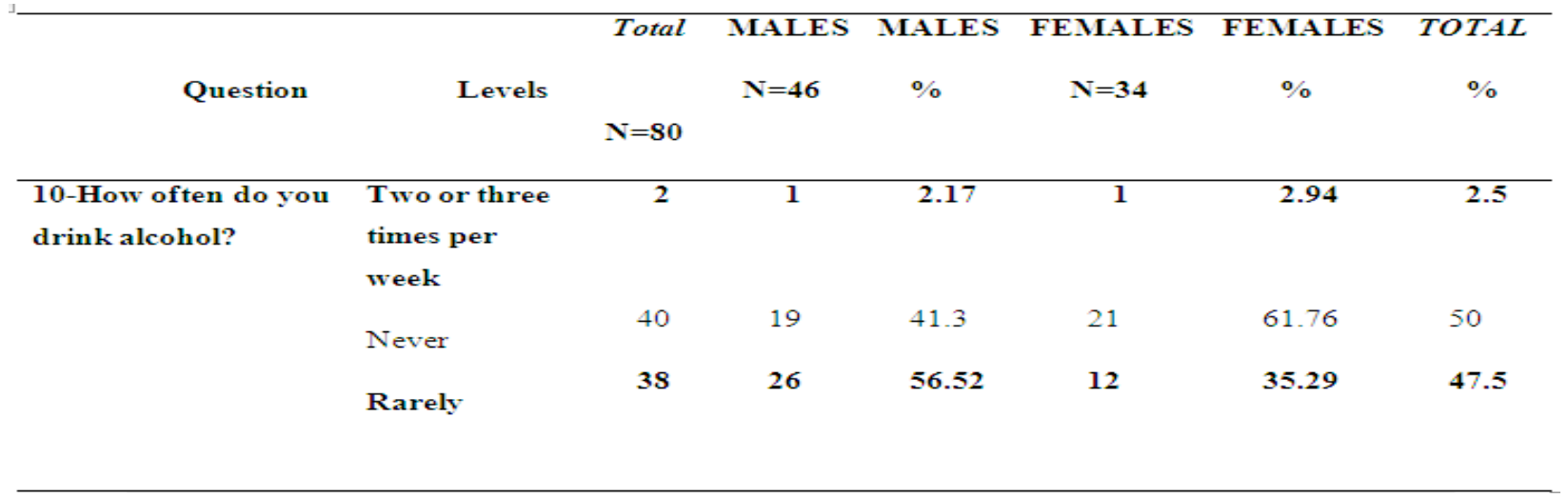

Table 13. Question 11. Please state your smoking history.

\begin{tabular}{|c|c|c|c|c|c|c|c|}
\hline \multirow[t]{2}{*}{ Question } & Levels & Total & $\begin{array}{l}\text { MALES } \\
\text { N=46 }\end{array}$ & $\begin{array}{c}\text { MALES } \\
\%\end{array}$ & $\begin{array}{c}\text { FEMALES } \\
\mathrm{N}=\mathbf{3 4}\end{array}$ & $\begin{array}{c}\text { FEMALES } \\
\%\end{array}$ & $\begin{array}{c}\text { TOTAL } \\
\%\end{array}$ \\
\hline & & $\mathrm{N}=\mathbf{8 0}$ & & & & & \\
\hline \multirow{4}{*}{$\begin{array}{l}\text { 11-Please state your } \\
\text { smoking history }\end{array}$} & At least 1 & 15 & 11 & 23.91 & 4 & 11.76 & 18.75 \\
\hline & packet & 9 & 7 & 15.21 & 2 & 5.88 & 11.25 \\
\hline & Rarely & 56 & 28 & 60.86 & 28 & 82.35 & 70 \\
\hline & Never smoke & & & & & & \\
\hline
\end{tabular}

\section{DISCUSSION}


The purpose of this study was to assess the prevalence of overweight and obesity and examine eating habits in a sample of Sport University of Tirana students. Body mass index was used to assess weight status. Based on BMl classification of weight status, findings of this study indicate that the majority of students were of normal weight. Normal weight was more prevalent among females (82.6\%) as compared to males $(73.7 \%)$, whereas, overweight and obesity were more common among male than female students. Prevalence of overweight was $23.6 \%$ in males as compared to $10.3 \%$ in females. Obesity was no problem for both genders. A total of $2.2 \%$ of the males were obese compared to $1.2 \%$ of the females. The lower rate of obesity among female students is expected since females are more cautious about their weight status than males, due to society perceptions which encourage females to be slender. This assumption was supported by the fact that only $0.5 \%$ of males were underweight as compared to $5.9 \%$ of females in this studied sample. Obviously, pictures of movie stars and models in fashion magazines and mass media have a strong impact on girls' body shape and image perception (Field et al., 1999). University Sport girls see the shape and weight of fashion models as the ideal body shape and figure to attain. Girls with such strong body weight perception can be at risk of developing eating disorders (Taylor et al., 1998). Similar findings of prevalence of obesity among male university students were reported in recent studies (Arroyo et al., 2006; Betsias et al., 2003). In this study, data analyses of students' eating habits revealed that the majority of students eat meals irregularly and eat breakfast daily (42.5\%), or rarely (30\%). $15 \%$ of the students eat meals three times per day. As expected, intake of colored vegetables and fruits was also common among students. Alcohol intake and smoking were common among students. The majority of students believe that eating meat, vegetables and other foods will provide them with a balanced diet. $43.47 \%$ male students and $52.94 \%$ female students in this study agreed that it is important to eat a variety of foods to have a balanced and nutritious diet. Daily intake of snacks was reported by $(25 \%)$ of students and the majority (32.5\%) was once or twice per week. The unhealthy eating habit of students was noticed in the intake of fried food (majority $47.5 \%$ were reported eating fried food three or four times per week), because $58.2 \%$ of them are living not with their parents but with friends. Frequent snacking and eating fried food can adversely affect students' health status, given the abundance of energy dense and high fat ingredients they contain. Improving students' knowledge about nutrition and healthy eating habits may promote healthy body weight management among students and reduce the prevalence of overweight and obesity. Therefore, developing nutrition education programs that promote healthy eating habits for university students should be encouraged. Alcohol intake and smoking were common in our sample of sport students, much better if we compare with the data of the last study of January 2012.

\section{CONCLUSION}

Despite the low prevalence of overweight and obesity in the studied university students' sample, results indicate that university students would benefit from a nutrition and health promotion program to reduce the tendency of overweight and obesity among students, particularly males, and to improve students' eating habits. Government, schools and individuals have different responsibilities for the prevention of obesity which is one of the major health problems of our age. Government should encourage the public and individuals for a healthy life style by developing effective and widespread policies directed to the prevention of obesity, by providing correct information sources and vary opportunities. Individuals, students too however, should demand services, should benefit from the opportunities provided by the government, should adopt a life style based on the gained adequate and balanced diet and regular physical activity habits.

\section{ACKNOWLEDGEMENTS}


A special note of appreciation goes to all our students of first grade of Faculty of Physical Activity and Recreation (SUT).

\section{REFERENCES}

1. Arroyo, M., Rocandio, A.M., Ansotegui, L., Pasual, E., Salces, I. \& Rebato, E. (2006). Diet Quality, Overweight and Obesity in Universities Students. Nutr Hosp, 21(6), pp.673-679.

2. Bertsias, G., Mammas, I., Linardakis, M. \& Kafatos, A. (2003). Overweight and obesity in relation to cardiovascular disease risk factors among medical students in Crete, Greece. BMl for Adults [http://www.nhlbisupport.com/bmi/bmi-m.htm].

3. BMCPublicHealth (2003), 3(3).

4. Field, A.E., Cheung, L., Wolf, A.M., Herzog, D.B., Gortmaker, S.L. \& Colditz, G.A. (1999). Exposure to the mass media and weight concerns among girls. Pediatrics, 103(3), pp.E36.

5. Food safety As in Mediterranean countries, the staples in Albania.www.albaglobal.com.

6. Human Nutrition, Nutrition Country Profile, Lebanon [http://www.fao.org/ag/agn/nutrition/lbn_en.stm]

7. Sakamaki, R., Amamoto, R., Mochida, Y., Shinfuku, N. \& Toyama K.A. (2005). Comparative study of food habits and body shape perception of university students in Japan and Korea. Nutr J, 4, pp.31.

8. Taylor, C.B., Sharpe, T., Shisslak, C., Bryson, S., Estes, L.S., Gray, N., McKnight, K.M., Crago, M., Kraemer, H.C. \& Killen, J.D. (1998). Factors associated with weight concerns in adolescent girls.Int J Eat Disord, 24, pp.31-42. 